Jurnal Keperawatan Silampari

Volume 3, Nomor 2, Juni 2020

e-ISSN: 2581-1975

p-ISSN: 2597-7482

DOI: https://doi.org/10.31539/jks.v3i2.897

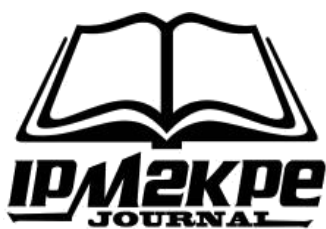

\title{
FAKTOR PREDISPOSISI PERILAKU KESEHATAN PENDERITA DIABETES MELLITUS TIPE 2
}

\author{
Sasmiyanto \\ Universitas Muhamdiyah Jember \\ sasmiyanto1@gmail.com
}

\begin{abstract}
ABSTRAK
Tujuan penelitian ini adalah untuk mencari faktor dominan yang mempengaruhi perilaku hidup sehat pada penderita diabetes mellitus di Kabupaten Bondowoso. Metode yang digunakan dalam penelitian ini adalah penelitian korelasional dengan pendekatan cross sectional. Hasil penelitian menunjukkan faktor predisposisi berupa pengetahuan, keyakinan, kepercayaan dan sikap secara simultan berpengaruh pada perilaku kesehatan penderita diabetes mellitus dengan nilai $\mathrm{R}$ sebesar 0,809 dan secara terpisah faktor sikap merupakan faktor predisposisi dominan penentu perilaku kesehatan penderita diabetes mellitus dengan nilai $\mathrm{p}$ value 0,000 . Simpulan, sikap responden terhadap kondisinya yang menderita diabetes mellitus mempengaruhi tindakan responden untuk mencari pertolongan kesehatan untuk mengelola gejala ataupun melakukan perawatan terhadap komplikasi yang dialami.
\end{abstract}

Kata Kunci : Diabetes Mellitus Tipe 2, Faktor Predisposisi, Perilaku Kesehatan

\section{ABSTRACT}

The purpose of this study was to look for dominant factors that influence healthy living behavior in people with diabetes mellitus in Bondowoso Regency. The method used in this research is correlational research with cross sectional approach. The results showed that predisposing factors such as knowledge, beliefs, beliefs and attitudes simultaneously affected the health behavior of people with diabetes mellitus with an $R$ value of 0.809 and separately the attitude factor was the dominant predisposing factor determining the health behavior of people with diabetes mellitus with a $p$ value of 0,000. Conclusion, the attitude of the respondent to his condition suffering from diabetes mellitus influences the respondent's actions to seek medical help to manage the symptoms or to take care of the complications experienced.

Keywords: Diabetes Mellitus Type 2, Predisposing Factors, Health Behavior

\section{PENDAHULUAN}

Diabetes mellitus tipe 2 merupakan penyakit metabolik akibat perubahan pada sel beta pankreas yang berefek pada munculnya kondisi hiperglikemia pada penderita. Diabetes mellitus tipe 2 merupakan salah satu penyakit tidak menular yang banyak diderita oleh penduduk di Indonesia dan dunia bahkan telah menjadi masalah kesehatan yang penting. Diabetes mellitus ditetapkan menjadi satu dari empat penyakit tidak menular yang menjadi target prioritas masalah. Diabetes mellitus telah ditetapkan sebagai bagian dari agenda untuk Tujuan Pembangunan Berkelanjutan tahun 2030, 
dimana negara anggota berkomitmen untuk menurunkan angka kematian akibat penyakit tidak menular termasuk diabetes mellitus menjadi sepertiganya supaya dapat mendapat Universal Health Coverage (UHC) dan menyediakan obat-obatan esensial yang terjangkau pada tahun 2030 (Kementerian kesehatan Repubelik Indonesia, 2018).

Lebih lanjut Kementrian Kesehatan RI menyebutkan bahwa secara global pada tahun 2014 penderita diabetes mellitus tipe 2 berjumlah 422 juta. Prevalensi diabetes mellitus di dunia mengalami peningkatan dari $4.7 \%$ menjadi $8.5 \%$. Pada beberapa dekade terakhir prevalensi diabetes mellitus di negara berpenghasilan rendah dan menengah diketahui lebih cepat dibandingkan negara berpenghasilan tinggi. Estimasi penderita diabetes mellitus di Indonesia pada tahun 2000 adalah 8,4 juta penduduk dan diperkirakan akan meningkat pada tahun 2013 menjadi 21,3 juta jiwa. Kondisi ini menempatkan Indonesia menjadi negara keempat dengan jumlah penderita diabetes mellitus terbanyak di dunia.

Di Indonesia hasil Survey Kesehatan Rumah Tangga (SKRT) 1995-2001 dan Riskesdas 2007 menunjukkan penyakit tidak menular seperti stroke, hipertensi, diabetes mellitus dan penyakit jantung menjadi penyebab kematian utama di Indonesia. Tahun 2007 sebanyak 59,5\% kematian di Indonesia disebabkan oleh penyakit tidak menular. Data Riskesdas 2018 menyebutkan prevalensi diabetes mellitus mengalami peningkatan. Prevalensi diabetes mellitus menurut konsensus Perkeni 2015 pada penduduk $\geq 15$ tahun meningkat sebanyak 10,9\%. Jawa Timur berada pada urutan kelima provinsi di Indonesia dengan prevalensi diabetes mellitus tertinggi mencapai 2,6\% di tahun 2018 meningkat dari tahun 2013 sebesar 2,1\%. Sedangkan di Jawa Timur, prevalensi diabetes mellitus berada pada kisaran $1,25 \%$ dari seluruh jumlah penduduk (Dinkes, 2018).

Faktor utama yang menyebabkan peningkatan angka kejadian diabetes mellitus adalah perubahan gaya hidup akibat pengaruh sosial dan urbanisasi yang gencar. Beberapa bentuk gaya hidup kurang sehat dapat berupa gaya hidup kurang gerak, kebiasaan mengkonsumsi makanan cepat saji, stres dan kelelahan. Kondisi ini tidak hanya terjadi di negara maju, namun juga banyak terjadi di negara berkembang atau pun negara dengan penghasilan rendah.

Hasil riskesdas 2018 mencatat 13,6\% penduduk dewasa di Indonesia mengalami overweight dan $21,8 \%$ mengalami obesitas. Proporsi obesitas sentral mencapai $31 \%$ pada tahun 2018. Proporsi konsumsi tembakau pada laki - laki mencapai 62,9\% dan kebiasaan merokok pada remaja 10 - 18 tahun, mencapai 23,91\% dari seluruh penduduk Indonesia. Data ini menunjukkan bahwa masih banyak penduduk di Indonesia yang berperilaku kurang sehat sehingga memicu terjadinya penyakit metabolik seperti diabetes mellitus (Riskesdas, 2018).

Diabetes mellitus tidak hanya merupakan masalah kesehatan namun juga masalah permasalahan ekonomi. Penderita diabetes mellitus umumnya adalah orang - orang yang masih berada pada fase produktif. Diabetes mellitus merupakan penyakit metabolik yang muncul akibat berbagai macam faktor resiko baik yang dapat diubah maupun tidak dapat diubah seperti gaya hidup, pola konsumsi, pola aktifitas, usia, jenis kelamin dan stres. Terjadinya diabetes mellitus memerlukan peran faktor resiko secara bersama-sama, sehingga satu faktor resiko saja belum cukup untuk menimbulkan diabetes mellitus. Berdasarkan pengamatan peneliti terhadap masyarakat Kabupaten Bondowoso, didapatkan data bahwa mayoritas penduduk Bondowoso adalah suku Madura, beragama Islam dan sebagian besar bermata pencaharian sebagai petani. Pengamatan yang dilakukan oleh peneliti menemukan suatu kebiasaan dari masyarakat 
di daerah Kabupaten Bondowoso yang dapat berkontribusi terhadap kejadian diabetes mellitus. Kebiasaan yang dilakukan oleh masyarakat adalah mereka sering melakukan selametan atau hajatan untuk memperingati persitiwa penting atau mensyukuri sesuatu.

Dalam acara selametan tersebut untuk menghormati tamu, tuan rumah biasanya akan menghidangkan teh manis dan kue jenang dodol yang memiliki kandungan gula tinggi serta makanan utama berkarbohidrat dan berlemak. Budaya suku Madura menyebutkan bahwa sebagai penghormatan kepada tuan rumah tamu berkewajiban mengkonsumsi sajian tersebut. Semakin banyak sajian yang dihabiskan dianggap menghormati tuan rumah. Selain itu didapatkan pula data yang menyebutkan bahwa mayoritas penduduk berpersepsi bahwa jika belum makan nasi maka dianggap belum makan. Dengan demikian penduduk Bondowoso dapat dikatakan memiliki pola konsumsi gula dalam jumlah yang tinggi. Hal lain yang ditemukan oleh peneliti adalah bahwa penduduk yang bermata pencaharian sebagai petani jarang melakukan olahraga karena menganggap aktifitas fisik harian mereka sudah merupakan olahraga. Wawancara yang dilakukan terhadap seorang penderita diabetes mellitus juga mengatakan bahwa memiliki diabetes mellitus adalah suatu hal yang wajar selama tidak ada luka karena responden memiliki riwayat keluarga dengan diabetes mellitus.

Teori precede-proceed menyebutkan kesehatan seseorang dipengaruhi oleh 2 faktor pokok yaitu faktor perilaku dan lingkungan. Perilaku penderita diabetes mellitus sangat dipengaruhi oleh persepsi penderita diabetes mellitus terhadap faktor resikonya.Perilaku dan gaya hidup merupakan faktor yang timbul karena adanya aksi dan reaksi seseorang dengan lingkungan. Faktor perilakuu muncul saat ada rangsangan dan gaya hidup adalah pola kebiasaan yang muncul akibat trend yang berlaku dalam kelompoknya. Sehingga rangsangan tertentu menimbulkan perilaku tertentu dan perilaku ditentukan oleh 3 faktor yaitu predisposing factor, enabling factor dan reinforcing factor (Gunawan, Dewi, 2018).

Diabetes mellitus adalah penyakit yang tidak dapat disembuhkan namun dapat dikontrol gejalanya. Pengontrolan gejala diabetes dapat dilakukan dengan melakukan aktifitas seperti menurunkan indeks massa tubuh, melakukan diet sehat dan meningkatkan aktifitas fisik.

Kelebihan dari penelitian ini terletak pada faktor predisposisi perilaku kesehatan penderita diabetes mellitus tentang kepercayaan dan keyakinan. Faktor ini belum banyak diteliti sebelumnya khususnya di kabupaten Bondowoso. Berdasarkan data diatas faktor tersebut bisa mempengaruhi terjadinya penyakit diabetes mellitus.

\section{METODE PENELITIAN}

\section{Desain Penelitian}

Penelitian ini adalah penelitian korelasional dengan pendekatan cross sectional yang dilakukan di wilayah Kabupaten Bondowoso.

\section{Participant}

Populasi pada penelitian ini adalah pasien diabetes mellitus yang berkunjung ke klinik Holistic Care Bondowoso selama bulan Meret - Juni 2019 dengan rerata kunjungan sebanyak 243 orang. Responden pada penelitian ini adalah 90 orang penderita diabetes mellitus yang diambil dengan mengunakan purposive sampling. Kriteria inklusi pada penelitian ini adalah responden berusia lebih dari 17 tahun, mampu baca tulis, kooperatif, dapat mengambil keputusan sendiri. 


\section{Data Collection Procedure}

Data penelitian diambil dengan menggunakan kuisioner. Pasien yang datang berkunjung ke klinik holistic care dan dinilai layak menjadi responden diminta untuk menandatangani informconsent dan selanjutnya diminta untuk mengisi kuisioner.

\section{Ethical Consideration}

Penelitian ini dilakukan setelah mendapat persetujuan dari komisi etik di Fakultas Ilmu Kesehatan Universitas Muhammadiyah Jember. Peneliti memberikan penjelasan kepada calon responden mengenai tujuan, metode, manfaat, resiko serta prosedur pengambilan data selama proses penelitian. Peneliti menjamin kerahasiaan pada responden dan memberikan hak kepada responden bahwa responden dapat keluar saat proses penelitian kapanpun tanpa implikasi untuk perlakuan selanjutnya.

\section{Statistik Analisis}

Analisa data dilakukan dengan menggunakan software SPSS 20. Deskriptif statistik dilakukan untuk mengetahui karakteristik responden. Uji parametrik regresi linear berganda dilakukan untuk mengetahui faktor resiko dominan perilaku kesehatan penderita diabetes mellitus di Kabupaten Bondowoso.

\section{HASIL PENELITIAN Karakteristik Reponden}

Tabel. 1

Distribusi Frekuensi Karakteristik Responden Penderita Diabetes Mellitus

\begin{tabular}{ccc}
\hline Karakteristik & Jumlah & Prosentase \\
\hline Umur & & \\
$31-40$ & 9 & 10 \\
$40-50$ & 30 & 33 \\
$50-60$ & 45 & 50 \\
$60-70$ & 6 & 7 \\
\hline Jenis Kelamin & 12 & 13 \\
Laki - laki & 78 & 87 \\
Perempuan & & \\
Tingkat pendidikan & 9 & 10 \\
SD & 24 & 27 \\
SMP & 51 & 66 \\
SMA & 6 & 7 \\
Sarjana & & 7 \\
Pekerjaan & 6 & 67 \\
PNS & 60 & 10 \\
Wiraswasta & 9 & 16 \\
Buruh & 15 & \\
Ibu Rumah Tangga & & \\
Menikah & 90 & 67 \\
\hline Status Pernikahan & 60 & 33 \\
\hline Keikutsertaan Asuransi Kesehatan & 30 & \\
Ya & & \\
Tidak & & \\
\hline
\end{tabular}

(Sumber : Data Primer, 2019) 
Berdasakan tabel 1 dapat dilihat bahwasanya responden yang terlibat dalam penelitian ini $50 \%$ berusia 50 - 60 tahun, $87 \%$ berjenis kelamin perempuan, $66 \%$ lulus dari SMA, 67\% bekerja sebagai wiraswasta, seluruhnya menikah dan $67 \%$ memiliki asuransi kesehatan.

Tabel. 2

Distribusi Frekuensi Riwayat Penyakit Diabetes Mellitus Responden Penderita Diabetes Mellitus

\begin{tabular}{lcc}
\hline Karaketeristik & Jumlah & Prosentase \\
\hline Komorbid & & \\
Ya & 75 & 84 \\
Tidak & 15 & 16 \\
\hline Komplikasi & 60 & 67 \\
Ya & 30 & 33 \\
Tidak & & \\
\hline Lama sakit & 15 & 16 \\
$\quad$ Kurang dari 1 tahun & 75 & 84 \\
$\quad$ Lebih dari 1 tahun & & \\
\hline Gula darah acak & 24 & 27 \\
$\quad$ <200mg/dl & 66 & \\
$\quad>200 \mathrm{mg} / \mathrm{dl}$ & & 33 \\
\hline BMI & & 67 \\
Underweight & 30 & \\
Normal & 60 & \\
Overweight & & \\
Obesitas & & \\
\hline
\end{tabular}

(Sumber : Data Primer, 2019)

Berdasarkan tabel 2 karakteristik riwayat penyakit diabetes mellitus responden dapat dijelaskan sebagai berikut $67 \%$ klien tidak memiliki penyakit penyerta, $67 \%$ responden memiliki komplikasi berupa diabetic foot, $84 \%$ responden menderit penyakit lebih dari setahun, $73 \%$ responden memiliki kadar gula darah $>200 \mathrm{mg}$, dan $67 \%$ responden memiliki indek massa tubuh overweight. Faktor predisposisi yang diukur dalam penelitian ini adalah faktor yang berasal dari internal diri responden yang memudahkan responden untuk berperilaku.

Tabel. 3

Distribusi Frekuensi Faktor Predisposisi Perilaku Kesehatan Responden Penderita Diabetes Mellitus

\begin{tabular}{llcc}
\hline No & Faktor Predisposisi & Jumlah & Persentase (\%) \\
\hline 1 & Pengetahuan & & \\
& a. Baik & 14 & 16 \\
& b. Cukup & 64 & 71 \\
& c. Kurang & 12 & 13 \\
\hline 2 & Keyakinan & & \\
& a. Agama Islam & 80 & 88 \\
& b. Kristen & 10 & 12 \\
\hline 3 & Kepercayaan & & \\
& a. Baik & 46 & 51 \\
& b. Cukup & 36 & 40 \\
& c. Kurang & 8 & 9 \\
\hline
\end{tabular}




\begin{tabular}{rrlcc}
\hline 4 & Sikap & & & \\
& a. & Baik & 42 & 47 \\
b. & Cukup & 46 & 51 \\
& c. & Kurang & 2 & 2 \\
\hline
\end{tabular}

(Sumber : Data Primer, 2019)

Berdasarkan tabel 3 dapat dilihat bahwa sebanyak $71 \%$ responden memiliki pengetahuan yang cukup tentang diabetes mellitus, $88 \%$ responden beragama Islam, $51 \%$ responden memiliki kepercayaan yang baik dan $51 \%$ memiliki sikap yang cukup.

Tabel. 4

Distribusi Frekuensi Perilaku Kesehatan Responden Penderita Diabetes Mellitus

\begin{tabular}{llcc}
\hline No & Perilaku Kesehatan & Jumlah & Persentase (\%) \\
\hline & PerilakuKesehatan & & \\
& a. Perilaku sakit & 40 & 44 \\
& b. Perilaku sehat & 50 & 56 \\
& Jumlah & 90 & 100 \\
\hline
\end{tabular}

(Sumber : Data Primer, 2019)

Berdasarkan tabel 4 dapat dilihat bahwa dari total 90 responden, $56 \%$ responden menunjukkan perilaku sehat.

Tabel. 5

Hasil Uji Regresi Linier Berganda Faktor Resiko Dominan Perilaku Kesehatan Penderita Diabetes Mellitus

\begin{tabular}{cc}
\hline Variabel & P value \\
\hline Faktor resiko & $0,000^{\mathrm{b}}$ \\
Pengetahuan & 0,915 \\
Agama & 0,134 \\
Kepercayaan & 0,094 \\
Sikap & 0,000 \\
\hline $\mathrm{R}=0,809$ & $\alpha>0,05$ \\
\hline
\end{tabular}

(Sumber : Data Primer, 2019)

Berdasarkan tabel 5 dapat dilihat bahwa seluruh faktor predisposisi yang ada pada diri penderita diabetes mellitus di Kabupaten Bondowoso memiliki pengaruh terhadap perilaku kesehatan penderita dengan nilai $\mathrm{R} 0,809$. Secara terpisah faktor predisposisi yang paling berpengaruh terhadap perilaku kesehatan penderita diabetes mellitus adalah variabel sikap dengan $\mathrm{p}$ value 0,000 .

\section{PEMBAHASAN}

\section{Data Umum Responden}

Berdasarkan data pada tabel 1 dapat diketahui bahwa 50\% responden berusia 50 60 tahun. Usia 50 - 60 tahun merupakan peralihan dari masa dewasa tua ke masa lansia. Peralihan dari masa produktif dan memasuki masa pensiun. Pada tahapan ini individu mulai mengalami penurunan fungsi organ yang khas dialami oleh lansia. Penurunan fungsi organ juga terjadi pada fungsi pankreas dimana insulin yang disekresikan pankreas mulai mengalami peningkatan resistensi (Yosmar et al., 2018). Hal ini diperburuk dengan gaya hidup yang kurang sehat saat responden muda. Hal ini sejalan 
dengan penelitian Alva dkk yang menyebutkan resiko diabetes mellitus meningkat sejalan dengan peningkatan usia (Alva et al., 2017).

Mayoritas responden $(87 \%)$ yang terlibat dalam penelitian ini berjenis kelamin perempuan. Hal ini menandakan bahwasanya diabetisi mayoritas adalah perempuan. Sejalan dengan penelitian yang dilakukan oleh Harraiter dan Kautzky - Willer yang menyebutkan bahwa secara genetik dan hormonal perempuan beresiko mengalami gangguan metabolik akibat ketidakseimbangan hormonal seperti menarche dini, siklus tidak teratur, kadar hormon androgen yang tinggi,dan riwayat DM gestasional (Harreiter, Kautzky-Willer, 2018). Selain itu dilihat dari perspektif sosiokultural perempuan di Indonesia memiliki peranan besar dalam kegiatan domestik rumah tangga. Perempuan di Indonesia dididik untuk menjadi caregiver dan provider dalam keluarga dan di satu sisi dituntut untuk menghargai apa yang mereka miliki. Hal ini secara tidak langsung menyebabkan perempuan memiliki gaya hidup yang tidak sehat. Dalam kehidupan sehari - hari perempuan dituntut untuk melayani seluruh anggota keluarga, termasuk menemani anggota keluarga untuk makan. Saat makanan tidak habis, perempuan (ibu) akan menghabiskan sisa makanan supaya tidak ada makanan yang terbuang. Secara tidak langsung hal ini membuat perempuan mengalami peningkatan berat badan berlebih. Berat badan berlebih telah diketahui menjadi salah satu faktor resiko terjadinya diabetes mellitus karena terjadi resistensi insulin.

Mayoritas responden dalam penelitian ini berpendidikan SMA dan bekerja sebagai wiraswasta. Hal ini sesuai dengan penelitian Yosmar yang menyebutkan tingkat pendidikan yang tidak terlalu tinggi dan rendahnya pengetahuan berkontribusi terhadap tingginya angka kejadian penyakit (Yosmar et al., 2018).

Meski tingkat pendidikan responden tidak terlalu tinggi, namun dari segi pekerjaan responden bekerja sebagai wiraswasta dan memiliki perkenomian menengah ke atas. Perbaikan perekonomian menyebabkan perubahan gaya hidup menjadi serba instan dan tidak memperhatikan asupan nutrisi seimbang. Hal inilah yang berkontribusi terhadap tingginya angka kejadian diabetes mellitus. Pekerjaan responden sebagai wiraswasta menuntut mobilitas tinggi namun aktifitas fisik rendah. Rendahnya aktifitas fisik menyebabkan resiko menderita diabetes mellitus lebih besar karena kebutuhan akan insulin rendah sehingga kadar glukosa meningkat (Siregar, 2017).

Responden pada penelitian ini $87 \%$ diantaranya memiliki penyakit penyerta. Penyakit penyerta yang dimiliki responden adalah hipertensi. Sindrome metabolik seperti hipertensi, dilipidemia, obesitas dan disfungsi endotel sering mengiringi kondisi hiperglikemia. Saat terjadi peningkatan kadar gula, glukosa akan menempel pada dinding pembuluh darah dan akan terjadi proses oksidasi dimana dula darah bereaksi dengan protein dari dinding pembuluh darah menimbulkan AGEs (Advanced Glycosylated Endproducts). AGES merupakan zat yang terbentuk dari kelebihan gula dan protein yang saling berikatan dan merusak dinding dalam pembuluh darah, menarik lemak jenuh atau kolesterol dan menstimulasi terjadinya inflamasi. Leukosit, trombosit dan bahan lain akan menjadi satu bekuan plak yang membuat dinding pembuluh darah menjadi keras, kaku dan menimbulkan penyumbatan yang akan meningkatkan perubahan tekanan darah atau hipertensi. Selian itu Yosmar et al, (2018) menyebutkan bahwa konsumsi obat antihipertensi dari golongan Calcium Channel Blocker mampu memicu terjadinya diabetes mellitus.

Berdasarkan tabel 2 dapat terlihat bahwa $84 \%$ responden mengidap penyakit lebih dari setahun dan $73 \%$ lansia memiliki kadar glukosa darah acak lebih dari $200 \mathrm{mg} / \mathrm{dl}$. Kondisi ini menjustifikasi bahwa diabetes mellitus yang diderita oleh klien bersifat 
kronis. Kadar glukosa darah acak yang tinggi menunjukkan pengelolaan gejala diabetes yang kurang baik. Hal ini didukung data $67 \%$ responden memiliki komplikasi berupa diabeticfoot. Diabeticfoot terjadi ketika sirkulasi darah ke area distal tidak sempurna dan dipicu oleh adanya luka di daerah kaki. Penatalaksanaan diabetes membutuhkan waktu yang sangat lama dan membutuhkan motivasi yang konstan dari penderita serta dukungan dari keluarga.

Selain itu didapatkan data bahwa mayoritas indeks massa tubuh responden berada pada tahap overweight. Penambahan akumulasi jaringan lemak menyebabkan resistensi insulin meningkat. Yosmar et al, (2018) menyebutkan bahwa overweight dan obesitas mengakibatkan terhalangnya absorbsi glukosa ke dalam lemak dan otot sehingga glukosa dalam darah meningkat.

\section{Faktor Predisposisi Perilaku Kesehatan}

Berdasarkan teori preceed procede faktor predisposisi yang berkontribusi dalam memunculkan suatu perilaku kesehatan adalah pengetahuan, keyakinan, kepercayaan dan sikap. Tabel 3 menunjukkan mayoritas responden (71\%) memiliki pengetahuan yang cukup. Pengetahuan dipengaruhi oleh beberapa faktor internal seperti umur, tingkat pendidikan, pekerjaan, lingkungan dan sosial budaya. Mayoritas responden dalam penelitian ini berusia 50 - 60 tahun. Usia 50 - dan 60 tahun merupakan usia kematangan. Pada tahapan ini umumnya individu mampu menerima informasi baru, hanya terkadang penerimaan informasi baru terhalang oleh penurunan fungsi kognitif dan sensori akibat proses menua sehingga dapat terjadi keterbatasan dalam menerima informasi baru dan pada akhirnya responden memiliki tingkat pengetahuan yang rendah.

Berdasarkan tingkat pendidikan mayoritas responden lulus dari SMA dan mayoritas bekerja sebagai wiraswasta. Tingkat pendidikan SMA merupakan tingkat pendidikan yang dapat dikategorikan sebagai pendidikan rendah karena merupakan pendidikan dasar. Seseorang dengan tingkat pendidikan rendah relatif sulit menerima sesuatu hal yang baru. Sebaliknya sesoerang yang memiliki pendidikan lebih tinggi akan lebih mudah menerima hal baru dan cenderung lebih terbuka.

Latar belakang pekerjaan responden mayoritas adalah wiraswasta. Responden berprofesi sebagai pedagang. Pekerjaan ini membuat kesempatan responden untuk bertemu dengan orang baru semakin banyak dan kesempatan untuk bertukar informasi semakin meningkat. Namun keterbatan yang dimiliki responden terkait tingkat pendidikan menyebabkan akses terhadap informasi kesehatan mejadi terbatas. Hal ini membuat pengetahuan yang dimiliki oleh responden menjadi sedikit terbatas. Sehingga pengetahuan responden terkait penyakit dan penatalaksanaanya menjadi terbatas.

Tabel 3 menunjukkan $88 \%$ responden beragama Islam dan $12 \%$ beragama kristen protestan. Selain itu 50\% responden memiliki kepercayaan baik, $40 \%$ responden memiliki kepercayaan cukup. Keyakinan atau kepercayaan merupkan inti dari setiap perilaku manusia. Aspek ini merupakan acuan bagi individu untuk menentukan persepsi terhadap suatu stimulus. Keyakinan dan kepercayaan berhubungan dengan kekuatan yang lebih tinggi yang mengarahkan aplikasi perilaku kesehatan. Saat tubuh sakit dan emosi berada di luar kontrol, maka spiritualitas dan keyakinan spiritual menjadi satu satu dukungan yang tersedia untuk membentuk perilaku. Keyakinan berkitan dengan penilaian subjektif individu terhadap dunia sekitarnya, pemahaman individu mengenai diri dan lingkungannya (Ramdhani, 2016). Keyakinan dapat memperkuat sikap terhadap perilaku jika berdasarkan pada evaluasi yang dilakukan individu, diperoleh data bahwa perilaku itu dapat memberikan keuntungan baginya. 
Sikap responden berdasarkan tabel $351 \%$ responden memiliki sikap yang cukup dan $47 \%$ responden memiliki sikap yang baik. Sikap merupakan suatu keadaan sikap mental yang dipelajari, dan diorganisasi menurut pengalaman dan yang menyebabkan timbulnya pengaruh khusus atas reaksi seseorang terhadap orang - orang, objek - objek, dan situasi - siatuasi dengan siapa ia berhubungan. Mayoritas responden berusia 50 -60 tahun. Umur merupakan salah satu faktor pembentuk sikap. Usia responden yang sudah matang dan ditunjang dengan motivasi atau keinginan untuk sembuh membuat responden menjadi terbuka terhadap hal baru.

Faktor pendidikan juga turut menunjang pembentukan sikap oleh responden. Tingkat pendidikan menjadi salah satu komponen sikap saat individu mendapati timbulnya gejala yang merugikannya. Dal hal ini responden mengalami komplikasi berupa diabetic foot yang dapat membuat responden menjadi merupakan gejala tidak menyenangkan dan direpson positif dengan prubahan sikap oleh responden.

\section{Perilaku Kesehatan}

Perilaku kesehatan merupakan suatu bentuk perilaku yang berhubungan dengan upaya penderita diabetes mellitus dalam upaya mempertahankan kadar gula darah, memanajemen gejala lain dan meminimalkan komplikasi akibat diabetes mellitus. Diabetes mellitus diketahui tidak dapat disembuhkan. Namun apabila penderita memilkiki komitmen untuk melakukan pola perilaku hidup sehat maka perjalanan penyakit akan terkontrol.

Komponen perilaku kesehatan yang diukur dalam penelitian ini meliputi pola makan, pola aktivitas dan mekanisme koping. Tabel 4 menunjukkan 56\% responden memiliki perilaku sehat dan $44 \%$ responden menunjukkan perilaku sakit. Perilaku sehat menunjukkan pola kebiasaan yang ditunjukkan oleh responden dalam memanajemen gejala diabetes mellitus yang dialami dan mencegah kemungkinan komplikasi yang muncul.

Teori precede proceed yang disampaikan Green menyebutkan bahwa perilaku dibentuk oleh beberapa faktor predisposisi yaitu pengetahuan, kepercayaan, keyakinan dan sikap. Tabel 5 menunjukkan secara simultan keempat faktor predisposisi berpengaruh secara signifikan dengan nilai $\mathrm{R}$ sebesar 0,809. Namun secara terpisah faktor perilaku, kepercayaan dan keyakinan tidak mempengaruhi perilaku kesehatan. Faktor sikap yang berkontribusi terhadap pembentukan perilaku kesehatan (Gunawan, Dewi, 2018).

Sikap merupakan faktor determinan dari suatu tindakan. Sikap responden terhadap kondisinya yang menderita diabetes mellitus mempengaruhi tindakan responden untuk mencari pertolongan kesehatan untuk mengelola gejala ataupun melakukan perawatan terhadap komplikasi yang dialami.

Sikap seseorang dalam memodifikasi gaya hidupnya menjadi gaya hidup sehat sangat diperlukan untuk memperbaiki perilaku kesehatannya untuk mempertahankan status kesehatannya, dan tidak dapat dipungkiri bahwa kejadian diabetes mellitus erat kaitannya dengan gaya hidup seseorang (Von Arx et al., 2016)

Usia responden yang semakin matang menggambarkan kebijaksanaan tentang bagaimana gharus berespon terhadap stimulus yang tidak menyenangkan dalam hal ini adalah komplikasi diabetic foot. Kematangan tersebut berkontribusi dalam pembentukan sikap yang lebih positif dalam memberikan respon terhadap suatu 
perilaku. Sikap positif yang medasari pembentukan suatu perilaku akan menyebabkan perilaku menjadi lebih awet dan tidak berubah dalam jangka waktu yang lama.

\section{SIMPULAN}

Mayoritas responden yang terlibat dalam penelitian ini adalah perempuan, beragama slam, berusia 50 -60 tahun, bekerja sebagai wiraswasta. Sedangkan kondisi responden yang berkaitan dengan diabetes mellitus adalah mayoritas responden memiliki komorbid berupa hipertensi, memiliki komplikasi diabeticfoot, sakit lebih dari setahun dan memiliki indeks massa tubuh overweight dan memiliki nilai kadar gula darah acak lebih dari $200 \mathrm{mg} / \mathrm{dl}$.

Analisis dekripsi faktor predisposisi perilaku kesehatan menunjukkan mayoritas responden memeiliki pengetahuan yang cukup, beragama Islam, memiliki kepercayaan baik dan sikap yang cukup baik. Responden dalam penelitian ini mayoritas menunjukkan perilaku sehat, dalam hal ini responden berupaya melakukan perilaku yang bertujuan memanajemen gejala diabetes mellitus dan menyembuhkan komplikasi penyakit

Berdasarkan ahasil analisa regresi linear berganda didapatkan data bahwa sikap responden berkontribusi terhadap pembentikan perilaku kesehtaan.

\section{SARAN}

Dari hasil penelitian ini diharapkan tenaga kesehatan tidak hanya berfokus pada aspek kuratif dalam upaya pentalaksanaan diabetes mellitus. Diabetes mellitus diketahui merupakan penyakit kronis, sehingga tenaga kesehatan diharapkan mampu melakukan inovasi dalam melakukan pendekatan pada aspek preventif untuk memodifikasi gaya hidup ke arah yang sehat sehingga gejala diabetes terkontrol.

Selain itu keluarga sebagai orang terdekat klien selalu memberikan dukungan pada klien supaya motivasi klien untuk berperilaku sehat tetap terjaga.

\section{DAFTAR PUSTAKA}

Alva, M. L., Hoerger, T. J., Zhang, P., \& Gregg, E. W. (2017). Identifying Risk for Type 2 Diabetes in Different Age Cohorts: Does One Size Fit all? BMJ Open Diabetes Research and Care, 5(1), 1-7. https://doi.org/10.1136/bmjdrc-2017000447

Dinkes. (2018). Hasil Utama Riset Kesehatan Dasar Jawa Timur 2018. Jakarta: Badan Penelitian dan Pengembangan Kesehatan, Kementrian Kesehatan Republik Indonesia, $1-82$

Gunawan, Y. E. S., \& Dewi, S. R. (2018). Health Behavior of Essential Hypertension Patients in Public Health Center in Waingapu. Jurnal Kesehatan Primer, 3(1), 17. https://doi.org/https://doi.org/10.5281/jkp.v3i1.247

Harreiter, J., \& Kautzky-Willer, A. (2018). Sex and Gender Differences in Prevention of Type 2 diabetes. Frontiers in Endocrinology, 9, 1-15. https://doi.org/10.3389/fendo.2018.00220

Kementerian Kesehatan Repubelik Indonesia. (2018). Data dan Informasi Profil Kesehatan Indonesia 2018

Ramdhani, N. (2016). Penyusunan Alat Pengukur Berbasis Theory of Planned Behavior. Buletin Psikologi, 19(2), 55-69. https://doi.org/10.22146/bpsi.11557

Riskesdas. (2018). Hasil Utama Riset Kesehatan Dasar. Kementrian Kesehatan Republik Indonesia, 1-100. https://doi.org/1 Desember 2013 
Siregar, P. S. (2017). Pengaruh Faktor Perilaku terhadap Terjadinya DM Tipe 2 pada Pengunjung DM di Klinik Puskesmas Sering. Igarss 2017, X, 1-5. https://doi.org/10.1007/s13398-014-0173-7.2

Von Arx, L. B. W., Gydesen, H., \& Skovlund, S. (2016). Treatment Beliefs, Health Behaviors and Their Association with Treatment Outcome in Type 2 Diabetes. BMJ Open Diabetes Research and Care, 4(1). https://doi.org/10.1136/bmjdrc2015-000166

Yosmar, R., Almasdy, D., \& Rahma, F. (2018). Survei Risiko Penyakit Diabetes Melitus terhadap Kesehatan Masyarakat Kota Padang. Jurnal Sains Farmasi dan Klinis, 5, 134-141 